\title{
EFEKTIVITAS PIJAT OKSITOSIN DAN AROMATERAPI CLARY SAGE TERHADAP ONSET LAKTASI
}

\author{
Ranny Septiani*, Martini*, Lia Fitri Andini* \\ *Jurusan Kebidanan Poltekkes Tanjungkarang \\ E-mail: koeny.rani@gmail.com
}

\begin{abstract}
Onset laktasi tertunda tidak jarang ditemukan pada ibu postpartum karena pengeluaran ASI merupakan suatu interaksi yang sangat komplek antara rangsangan mekanik, saraf dan bermacam-macam hormon yang berpengaruh terhadap pengeluaran oksitosin. Data keterlambatan onset laktasi di salah satu PMB di Kota Metro tahun 2018 dialami oleh 73\% ibu postpartum. Metode untuk mempercepat onset laktasi dengan cara melakukan pijat oksitosin dan aromatrapi clary sage. Jenis penelitian kuantitatif, rancangan yang digunakan adalah quasi eksperimen dengan pendekatan non equivalent control group. Populasi pada penelitian ini adalah seluruh ibu postpartum yang belum mengeluarkan kolostrum 2 jam setelah melahirkan dengan jumlah sampel sebanyak 38 orang yang dibagi dalam dua kelompok. Cara pengumpulan data menggunakan kuesioner dengan wawancara dan observasi. Penelitian ini menghitung rata-rata onset laktasi pada uji univariat dan melihat perbedaan efektivitas pijat oksitosin dan aromaterapi clary sage dibanding pijat oksitosin terhadap onset laktasi pada uji bivariat. Uji statistik yang digunakan adalah Mann-Whitney. Hasil penelitian meunjukan rata-rata onset laktasi pada kelompok pijat oksitosin dan aromaterapi clary sage adalah 4,21 jam, sedangkan pada kelompok pijat oksitosin adalah 6,37 jam. Hasil uji statistik bivariat menunjukkan hasil $p$ value $0.000(\mathrm{p} \leq \alpha 0.05)$. Kesimpulan dari penelitian ini adalah pijat oksitosin dan aromaterapi clary sage lebih efektif dibanding pijat oksitosin. Saran untuk tenaga kesehatan terutama bidan agar menerapkan teknik pemberian pijat oksitosin dan aromaterapi clary sage untuk mempercepat onset laktasi.
\end{abstract}

Kata kunci: clary sage, onstel laktasi, pijat oksitosin, salvia sclarea

\section{LATAR BELAKANG}

Onset laktasi merupakan masa permulaan untuk memperbanyak air susu sampai air susu keluar pertama kali atau presepsi ibu kapan air susunya keluar (come in) yang ditandai dengan payudara terasa keras, berat, bengkak sampai air susu atau kolostrum keluar. Onset laktasi disebut juga laktogenesis tahap II, dimulai sejak 24 jam postpartum, ditandai dengan payudara terasa penuh, payudara terasa besar atau membengkak dan air susu merembes (Chapman \& Esacamilla, 2000).

Onset laktasi tertunda tidak jarang ditemukan pada ibu postpartum karena pengeluaran ASI merupakan suatu interaksi yang sangat komplek antara rangsangan mekanik, saraf dan bermacammacam hormon yang berpengaruh terhadap pengeluaran oksitosin. Pengeluaran hormon oksitosin selain dipengaruhi oleh isapan bayi juga dipengaruhi oleh reseptor yang terletak pada sistem duktus, bila duktus melebar atau menjadi lunak maka secara reflektoris dikeluarkan oksitosin oleh hipofise yang berperan untuk memeras air susu dari alveoli Onset laktasi tertunda yang terjadi di Indonesia dilaporkan mencapai $31 \%$ ibu postpartum (Puspita. L.R \& Nursanti. I, 2013).

Pemberian ASI pada masa-masa awal sangat dianjurkan karena memberi manfaat kesehatan untuk ibu dan bayi. Pemberian ASI hari pertama akan menyelamatkan $16 \%$ kematian neonatal dan menyusu dini 1 jam pertama akan menyelamatkan 22\% kematian balita pertahun (Endah. N.S \& Masdinarsah. I, 2011). Proses menyusui tidak selalu berjalan mulus, ada berbagai kendala yang menghalangi atau mempersulit proses menyusui salahsatunya adalah onset menyusui yang lebih lambat.

Dampak onset laktasi salah satunya adalah kegagalan dalam pemberian ASI ekslusif. Persentase pemberian ASI eksklusif pada bayi 0-6 bulan di Indonesia pada tahun 2012 hanya sebesar 48,6\%. Persentase pemberian ASI eksklusif terendah terdapat di Provinsi Papua Barat sebesar 20,57\%. Persentase pemberian ASI 
eksklusif di Provinsi Lampung pada tahun 2012 juga hanya mencapai 40,56\%. ${ }^{4}$ ) Cakupan mendapat ASI eksklusif di Provinsi Lampung tahun 2015 sebesar $57,70 \%$ dimana angka ini masih di bawah target yang diharapkan $80 \%$ (Dinas Kesehatan Provinsi Lampung, 2015).

Di Kota Metro Berdasarkan laporan pada tahun 2016 didapatkan bahwa dari 2.762 sasaran bayi hanya 925 bayi yang mendapatkan ASI eksklusif (48\%). Angka cakupan ASI eksklusif belum mencapai target yaitu sebesar $60 \%$. Jumlah bayi yang diberi ASI eksklusif di kecamatan Ganjar Agung adalah sebanyak 88 (32\%) bayi dari jumlah keseluruhan 271 bayi usia 0-6 bulan (Dinas Kesehatan Kota Metro, 2016).

Salah satu penyebab kegagalan pemberian ASI eksklusif pada bayi diakibatkan oleh onset laktasi yang terlambat (Hruschka,et al. 2003). Pada awal masa menyusui ibu akan merasa panik,khawatir dan cemas mendengar tangisan bayi yang diasumsikan bayi lapar, karena ASI belum keluar maka akhirnya ibu memutuskan memberikan susu formula untuk meredakan tangisan bayi. Keputusan ini tidak akan diambil jika ASI keluar pada hari pertama atau 1 x 24 jam post partum (Tantina, Umey, 2015).

Onset laktasi yang terlambat dapat disebabkan oleh berbagai macam faktor diantaranya adanya faktor psikologis ibu, usia ibu postpartum, dan proses inisiasi menyusu dini (IMD). Faktor psikologis ibu terjadi karena ibu mengalami kecemasan, kecemasan merupakan respon emosional terhadap penilaian yang menggambarkan khawatir, gelisah, takut, tidak tentram disertai berbagai keluhan fisik (Suprijati, 2014), sehingga jelas bahwa kecemasan sangat mempengaruhi terjadinya keterlambatan onset laktasi (Wulandari. F.T,dkk, 2014).

Dalam upaya pengeluaran ASI ada 2 hal yang mempengaruhi yaitu produksi dan pengeluaran. Produksi ASI dipengaruhi oleh hormon prolaktin dan pengeluaran ASI dipengaruhi hormon oksitosin. Ibu menyusui penting menjaga suasana hati dan jiwa dalam kondisi baik dan bahagia.
Bila ibu mengalami kecemasan, stress maka produksi oksitosin bisa terhambat dan pada akhirnya akan menghambat proses keluarnya ASI. Banyak cara yang dilakukan untuk menjaga kondisi psikologis ibu pada awal masa menyusui mencegah atau mengatasi kecemasan yang ibu rasakan misalnya melakukan pijatanpijatan lembut pada tubuh ibu atau penggunaan aroma therapi melalui inhalasi yang juga dapat bermanfaat membuat ibu merasa tenang dan rileks sehingga hormon oksitosin keluar, ASI diproduksi. Pijat oksitosin merupakan salah satu cara yang digunakan untuk melancarkan produksi ASI melalui pijatan pada tulang belakang ibu, dengan dilakukan pijatan pada tulang belakang ibu akan merasa tenang, rileks, meningkatkan ambang rasa nyeri dan mencintai bayinya, sehingga dengan begitu hormon oksitosin keluar dan ASI pun cepat keluar (Wulandari. F.T,dkk, 2014).

\section{METODE}

Jenis penelitian kuantitatif dengan desain quasi eksperimen. Pendekatan yang digunakan pada penelitian ini adalah non equivalent control group, dalam rancangan ini sampel dibagi menjadi kelompok intervensi 1 dan intervensi 2.

Dalam penelitian ini ada dua kelompok, pertama kelompok perlakuan kombinasi pijat oksitosin dengan aromaterapi clary sage dan kelompok kedua perlakuan dengan pijat oksitosin. Lalu dilakukan pengukuran onset laktasi sebelum intervensi pada masing masing kelompok untuk memastikan belum terdapat pengeluaran kolostrum, dilanjutkan dengan intervensi sesuai dengan kelompok masing-masing kemudian dilakukan pengukuran onset laktasi setelah intervensi pada kedua kelompok tersebut untuk melihat pada jam keberapakah kolostrum keluar setelah persalinan. Uji statistik yang digunakan adalah Mann-Whitney. 
HASIL

Tabel 1: Perbedaan Efektifitas Pijat Oksitosin dan Aromaterapi Clary Sage Dengan Pijat Oksitosin Terhadap Onset Laktasi

\begin{tabular}{|c|c|c|c|c|c|}
\hline Intervensi & $\mathrm{n}$ & Mean & SD & $\mathrm{SE}$ & $p$ value \\
\hline $\begin{array}{l}\text { Pijat oksitosin dan } \\
\text { aromaterapi clary } \\
\text { sage }\end{array}$ & 19 & 4,21 & 0,855 & 0,196 & 0,000 \\
\hline ijat oksitosin & 19 & 6,37 & 1,212 & 0,287 & \\
\hline
\end{tabular}

Hasil uji statistik yang ditunjukkan pada tabel di atas menunjukkan nilai $p=$ 0,000 . Dasar pengambilan keputusan pada penelitian adalah jika $\mathrm{p} \leq \alpha(0,05)$ maka H0 ditolak, yang ada perbedaan onset laktasi antara pijat oksitosin dan aromaterapi clary sage dengan pijat oksitosin. Karena rata-rata onset laktasi kelompok pijat oksitosin dan aromaterapi clary sage lebih cepat dibanding pijat oksitosin. Sehingga disimpulkan pijat oksitosin dan aromaterapi clary sage lebih efektif dibanding pijat oksitosin.

\section{PEMBAHASAN}

Berdasarkan hasil uji analisis Mann Whitney perbedaan antara kelompok pijat oksitosin dan aromaterapi clary sage terhadap onset laktasi yang dilakukan terhadap 38 responden pada kelompok dengan intervensi pijat oksitosin dan aromaterapi clary sage didapatkan rata-rata onset laktasi adalah 4,21 jam, sedangkan pada kelompok intervensi pijat oksitosin adalah 6,37 jam. Hasil tersebut menunjukkan perbedaan rata-rata waktu onset laktasi, pada intervensi pijat oksitosin dan aromaterapi clary sage mempunyai rata-rata waktu yang lebih singkat jika dibandingkan dengan pijat oksitosin saja. Hasil penelitian juga menyimpulkan bahwa pijat oksitosin dan aromaterapi clary sage lebih efektif dibanding pijat oksitosin dalam mempengaruhi onset laktasi.

Produksi ASI sangat dipengaruhi oleh kondisi psikologis ibu menyusui. Saat ibu menyusui merasa nyaman dan releks pengeluaran oksitosin dapat berlangsung baik. Faktor oksitosin merupakan faktor yang mempengaruhi onset laktasi, karena dengan adanya oksitosin maka otot polos pada alveoli dapat berkontraksi dan mengeluarkan kolostrum. Pijat oksitosin adalah pemijatan pada sepanjang tulang belakang sampai tulang costae kelimakeenam merupakan usaha untuk merangsang hormon prolaktin dan oksitisin setelah melahirkan. Pijat oksitosin memberikan kenyamanan pada ibu sehingga merangsang pembentukan hormon oksitosin. Minyak essensial clary sage (salvia sclarea) merupakan aroma terapi yang digunakan secara inhalasi dapat menimbulkan efek rekasasi yang kuat, dapat menurunkan kecemasan, stress dan depresi.

Pijat oksitosin yang dikombinasikan dengan pengunaan aromaterapi clary sage (salvia sclarea) dapat bekerja maksimal untuk menghilangkan stress atau kecemasan yang ibu rasakan sehingga tubuh ibu mampu menghasilkan hormon oksitosin secara maksimal. Kedua intervensi ini bekerja secara bersama-sama untuk memaksimalkan pengeluaran hormon oksitosin dari hipotalamus yaitu hipofisis posterior

\section{KESIMPULAN}

Berdasarkan hasil penelitian dan pembahasan mengenai dapat disimpulkan bahwa rerata waktu yang dibutuhkan onset laktasi pada kelompok intervensi pijat oksitosin dan aromaterapi clary sage adalah 4,21 jam, sedangkan rerata waktu yang dibutuhkan onset laktasi pada kelompok intervensi pijat oksitosin adalah 6,37 jam. Sehingga intervensi dengan pijat okistosin dan aromaterapi berpengaruh lebih cepat pada onset laktasi daripada intervensi pijat oksitosin saja.

Hasil uji statitik menunjukan adanya perbedaan terhadap onset laktasi setelah pemberian pijat oksitosin dan aromaterapi clary sage dibanding pijat oksitosin dengan nila p-value sebesar 0,000. Sehingga disimpulkan bahwa pijat 
oksitosin dan aromaterapi lebih efektif mempengaruhi onset laktasi dibandingkan dengan pijat oksitosin saja.

Penelitian ini diharapkan dapat diterapkan oleh tenaga kesehatan terutama bidan, mahasiswa, ibu menyusui maupun suami dan para pembaca untuk dapat menerapkan teknik pijat oksitosin dan aromaterapi clary sage untuk mempercepat onset laktasi.

\section{DAFTAR PUSTAKA}

Chapman, and Esacamilla. (2000). Maternal Preception of Onset Lactation 128 Media Ilmu Kesehatan Vol. 2 No.3 Desember 2013, Public Health Indicatr of Lactogenesis Stage II. TheJournal of Nutrition.

Dinas Kesehatan Kota Metro. (2016). Profil Kesehatan Kota Metro Tahun 2016

Dinas Kesehatan Provinsi Lampung. (2015). Profil Kesehatan Provinsi Lampung Tahun 2015.
Endah, N.S \& Masdinarsah, I. (2011). Pengaruh Pijat Oksitosin Terhadap Pengeluaran Kolostrum Pada Ibu Post Prtum di Ruang Kebidanan Rumah Sakit Muhammadiyah Bandung Tahun 2011, Bandung.

Hruschka,et al. (2003). Delayed Onset Of Lactation and Risk of Ending Full Breast-Fedding Early in Rural Guatemala. The Journal of Nutrition.

Puspita, L.R. \& Nursanti, I. (2013). Kecemasan Menghambat Onset Laktasi Ibu Postpartum, Yogyakarta.

Tantina, Umey. (2015). Pengaruh Inisiasi Menyusu Dini Terhadap Waktu Pengeluaran ASI Pertama Pada Ibu PostPrtum di Wilayah Kerja Puskesmas Bergas Kabupaten Semarang, Semarang.

Wulandari, F.T, dkk. (2014). Pengaruh Pijat Oksitosin terhadap Pengeluaran Kolostrum pada Ibu Post Partum di Rumah Sakit Umum Daerah Provinsi Kepulauan Riau. 